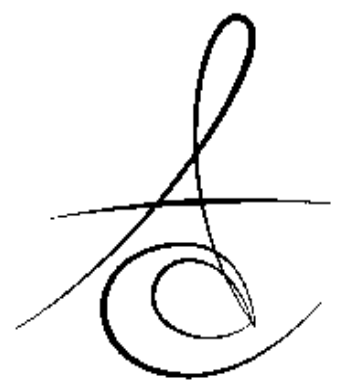

\title{
İMPLANT TEDAVİSİNDE DİAGNOSTİK GÖRÜNTÜLEME TEKNİKLERİNE BAĞLI KOMPLİKASYONLAR
}

\section{COMPLICATIONS RELATED TO DIAGNOSTIC IMAGING TECHNIQUES IN IMPLANT TREATMENT}

\author{
Prof. Dr. Gülfem ERGÜN*
}

\author{
Dr. Öğr. Üyesi Zeynep ŞAHİN**
}

Makale Kodu/Article code: 2916

Makale Gönderilme tarihi: 01.07.2016

Kabul Tarihi: 26.07.2016

öz

İmplant başarısının en önemli faktörlerinden birisi doğru tedavi planlamasıdır. Diagnostik görüntüleme, bu hedefin gerçekleştirilmesinde önemli bir rol oynar. Görüntüleme tekniği hem anatomiyi dikkate almalı hem de boyutsal doğruluğu sağlamalıdır. Film boyutlarının kısıtlı olması, görüntüdeki distorsiyon, büyüme ve iki boyutlu görüntü bazı olgularda radyografinin kulanımını sınırlar. Geleneksel radyografi ile ilgili dezavantajlar nedeniyle bilgisayarlı tomografi ve konik ışınlı bilgisayarlı tomografi gibi ileri teknolojiler daha çok tercih edilmektedir. İmplant cerrahi uygulamasında kaçınılması gereken başarısızlıklardan birisi komşu yapıların zarar görmesidir. Bu komplikasyonların arasında en önemlileri paranasal sinüsün perfore olması, komşu dişin kökünün zarar görmesi, kortikal tabakanın, damarların, kanalın ve daha da önemlisi sinirlerin perfore edilmesidir. Cerrahi bölgeye implant planlamasının transfer edilmesindeki en güncel yaklaşım, interaktif bilgisayar yazılım programları yardımı ile bilgisayar destekli tasarım ve bilgisayar destekli üretim tekniğinin kullanılmasıdır. Bu güncel gelişmeler ve ileri görüntüleme teknikleri, implant tedavisinin başarısını artırmada ve önemli komplikasyonların önlenmesinde rol oynamaktadır.

Anahtar Kelimeler: Tanısal görüntüleme, komplikasyonlar, bilgisayar yardımlı tasarım, konik ışınlı bilgisayarlı tomografi, diş implantı

\section{ABSTRACT}

One of the most important factors in implant success is proper treatment planning. Diagnostic imaging is an important tool to accomplish this task. On imaging, the modality should not only consider the anatomy but should also provide dimensional accuracy. Limited film size, image distortion, magnification and a twodimensional view restrict their use in some cases. Because of the drawbacks associated with traditional radiographs, higher technologies such as computed tomography and cone-beam computed tomography are better preferred. Injury to adjacent structures is an avoidable outcome of oral implant placement surgery. Paramount among these is perforation into paranasal sinüs; into neighboring tooth root; through cortical plate and into vessels, canals and most importantly, nerves. The most actual approach for the transfer of implant planning to the surgical site is to use computer-aided design/ computer-aided manufacturing technique. These actual developments and advanced imaging techniques; improving the success of the implant treatment, and plays an important role in the prevention of complications.

Keyswords: Diagnostic imaging, complications, Computer-Aided Design, Cone-Beam Computed Tomography, dental implant

\section{Gíriş}

Diagnostik görüntüleme tekniklerinin değerlendirilmesi implantın klinik başarısı ve uzun süre klinik kullanımı açısından önemlidir. Planlama aşamasında protez, cerrahi ve radyoloji bölümleri arasında multidisipliner bir çalışma gerektirmektedir.

Dental implant çene kemiği içine cerrahi olarak yerleştirilen $^{1}$ hem fonksiyonel hem de estetik olarak kaybedilen dişin yerini tutması amaçlanan biyouyumlu

*Gazi Üniversitesi Diş Hekimliği Fakültesi Protetik Diş Tedavisi AD, Ankara

${ }^{* *}$ Mersin Üniversitesi Diş Hekimliği Fakültesi Protetik Diş Tedavisi AD, Mersin 
yapılardır $^{2,3}$. İmplant bir kaç ay içerisinde çene kemiğine osseointegre olmaktadır. Doğal diş fonksiyonuna benzer şekilde çiğneme ve ısırma kuvvetlerine karşı koyabilmektedir ${ }^{1}$. Osseointegrasyon, canlı kemik dokusu ile yükleme altındaki implant yüzeyi arasında direkt yapısal ve fonksiyonel bağlantı olarak tanımlanmıştır ${ }^{4,5}$. İmplant başarısının en önemli faktörlerinden birisi doğru tedavi planlamasıdır ${ }^{6}$. Diagnostik görüntüleme, osseointegre implantlar ile gerçekleştirilen oral rehabilitasyonda tedavi planlamasının önemli bir parçasını oluşturmaktadır ${ }^{7}$. İmplant yerleştirilecek bölgedeki anatomik yapılara zarar vermeden uygun radyolojik teknikler cerrahi rehber plaklar ve cerrahi girişimlerin öngörülerine rehberlik etmektedirler. Görüntüleme tekniği seçmek, en iyi boyutsal doğrulukla birlikte gerekli bilgileri elde etmede klinik başarıda önemli bir rol oynamaktadır. Radyolojik teknikler cerrahi öncesi, cerrahi sırasında (intraoperatif) ve protez sonrası implant görüntülemesinde önemlidir ${ }^{8}$.

\section{Görüntülemenin amaçları}

$\checkmark$ Kemik yüksekliğini ve genişliğini ölçmek (kemik boyutları)

$\checkmark \quad$ Kemik kalitesini belirlemek

$\checkmark \quad$ Alveoler kemiğin uzun eksenini belirlemek

$\checkmark$ İnternal anatominin yerini belirlemek ve tanımak

$\checkmark$ Çene sınırlarını belirlemek

$\checkmark \quad$ Altta yatan patolojiyi belirlemek ${ }^{9}$

Görüntüleme tekniğinin seçimi ve çekim zamanı bazı aşamaları içermektedir:

\section{İmplant cerrahisi öncesi görüntüleme}

Bu aşamadaki görüntülemede amaçlanan bütün gerekli cerrahi ve protetik bilgilerin ışığı altında kemiğin kalitesi ve miktarı, implant sahasının kritik yapılarla olan ilişkisi ve giriş açılarının (oriyantasyon) belirlenmesidir $^{8,10}$

\section{Cerrahi ve intraoperatif implant görüntüleme}

Bu aşamadaki görüntülemenin amacı cerrahi işlem sırasında ve hemen sonrasında cerrahi bölgelerin değerlendirilmesi, implantın en uygun pozisyon ve oryantasyonunun belirlenmesi, iyileşmenin, implant cerrahisinin bütünlüğünün, dayanak pozisyonunun ve protez yapımının doğruluğunun değerlendirilmesidir ${ }^{8,9}$.

\section{Protez sonrası implant qörüntülemesi}

Protez ağıza yerleştirildikten hemen sonra bu aşama başlar ve implant ağızda kaldığı sürece devam eder. Protez sonrası görüntüleme ve takiben yeniden çağırma ve kontrol seansındaki görüntüleme gibi radyografi dizisini içermektedir. İmplant çevresindeki kret kemik seviyeleri (alveolar kemik değişiklikleri) değerlendirilmektedir ${ }^{8,9}$.

\section{Görüntüleme Tekniklerinin Modelleri}

Sağlanacak faydanın verilebilecek zarara oranına göre yararın yüksek olduğu görüntüleme tekniklerinin seçimi radyolojinin temel ilkesi olmalıdır ${ }^{8}$. Dental implantların tedavi planlaması ve idamesinde periapikal radyografi, bite-wing radyografi, okluzal radyografi, sefalometrik radyografi, panoromik radyografi, transtomografi, dijital radyografi gibi geleneksel (konvansiyonel) teknikler ${ }^{9}$ ve manyetik rezonans görüntüleme, konvansiyonel tomografi, bilgisayarlı tomografi, konik ışınlı bilgisayarlı tomografi gibi gelişmiş teknikler ${ }^{11}$ olmak üzere bir çok görüntüleme tekniği kullanılmaktadır ${ }^{8}$.

\section{Bilgisayarlı Tomografi}

Bilgisayarlı Tomografi (BT) Hounsfield tarafından keşfedilmiş ve görüntülemede 1972 yılında kullanılmaya başlanmıştı ${ }^{10}$. BT, temporomandibular eklemde (TME), dentoalveolar lezyonlarda (kemik-diş lezyonları), maksillofasiyal deformitelerde ve maksillofasiyal bölgenin preoperatif ve postoperatif değerlendirilmesinde kullanılmaktadır ${ }^{8}$. Operasyon düşünülen implant bölgesinin görüntülerinin alınması sonrasında BT analizinde tanjantsal ve kesitsel tomografik görüntüleri tekrar formatlanır. Günümüz jenerasyonu BT'deki gelişmelerle birlikte BT tarayıcılar bir piksel (0.25 $\mathrm{mm}$ ) kalınlığında kesitler almakta ve 1 pikselin düzlemsel çözünürlük tarama aralığı $(0.5 \mathrm{~mm}-1.5 \mathrm{~mm})$ ile bu düzlemsel görüntü alanına benzer geometrik çözünürlüğü üretmektedirler. Yapıların görüntülemelerinde dansitelerinin tam olması, miktar tayininin yapılabilmesi sayesinde bölgedeki dokular birbirinden ayırt edilebilmekte ve kemik kalitesi belirlenebilmektedir ${ }^{8,9}$ (Tablo 1).

Tablo 1. Kemik Kalitesi

\begin{tabular}{|r|l|}
\hline Yoğunluk & Hounsfield Birimleri (BT sayıları) \\
\hline D1 & 1250 \\
\hline D2 & $850-1250$ \\
\hline D3 & $350-850$ \\
\hline D4 & $150-350$ \\
\hline D5 & $<150$ \\
\hline
\end{tabular}

(BT: Bilgisayarlı Tomografi)

BT, hastalıkların ayırt edilebilmesine, implant yerleştirilecek bölgenin vital yapılara yakınlığının belir-

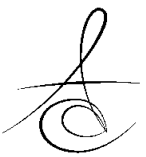


lenmesine ve dental implantların uygun pozisyon ve oriyantasyonunun belirlenmesine imkan verir ${ }^{8}$. Aynı zamanda kemik kalitesinin ve miktarının belirlenmesinde yararlanilır ${ }^{10}$. Bununla birlikte konvansiyonel BT ile yüksek radyasyon dozuna maruz kalınması ${ }^{10,12}$, maliyetinin yüksek olmasi ${ }^{9-11}$, metallerin görüntü artifaktlarına neden olması ${ }^{10,11}$, teknik hatalar ${ }^{9}$, görüntülerin yorumlanması için özel eğitim gerektirmesi ${ }^{9,11}$ gibi olumsuz özellikleri de bulunmaktadır.

Konvansiyonel BT'nin sınırlamalarının üstesinden gelebilmek için son zamanlarda çok kesitli heliksel BT tarayıcıları geliştirilmiştir ${ }^{8}$. Bu teknik veri elde etme esnasında hastanın hareketini ve nefes tutma zamanını azaltır. Daha hızı ve azalmış görüntü kirliliği ile genişletilmiş anatomik kapsama, azaltımış kısmi hacim etkisi ve yüksek kontrastlı bir görüntü oluşmasına neden olur. Bu teknik $0.5 \mathrm{~mm}$ 'lik doku dilimleri elde edilirken dilimlerin kalınlığını sağlamada sekiz kat daha hızıdır. Bu teknik, yeniden elde edilen verinin z eksenindeki çözünürlüğünde artış sağlamaktadır. Tüpün soğuması için gerekli olan bekleme süresi daha azdır ${ }^{8}$.

Konik Işınlı Bilgisayarlı Tomografi (Dental Volumetrik Tomografi)

Konvansiyonel medikal BT tarayıcıların dezavantajlarının üstesinden gelmek amacıyla dental uygulamalar için son zamanlarda yeni bir BT geliştirilmiştir. Bu teknik konik ışınlı bilgisayarlı tomografi (KIBT) olarak adlandırılır. KIBT tekniği kullanılarak görüntü elde etmek için $X$ ışını kaynağı ve dedektör rotasyon yapan bir gantry (sehpa)'ye sabitlenmiştir ${ }^{8}$. Bu teknikle konvansiyonel $\mathrm{BT}$ 'deki dedektörlerin radyasyon zararı minimalize edilmektedir?. Görüntünün tüm alanının veri setinin elde edilmesinde daha hızlı bilgi sağlamaktadır. Daha kısa inceleme süresi, daha iyi görüntü netliği, azalmıs görüntü distorsiyonu ve artmış $X$ ışını etkinliği (verimliliği) sağlamaktadır ${ }^{8}$.

Görüş alanının geniş olmasının en büyük dezavantajı dedektörün saçılma (scatter) radyasyonu nedeni ile oluşan görüntü kirliliği (noise) ve düşük kontrastlı çözünürlükte görüntü oluşmasıdır ${ }^{9}$. Kompakt yüksek kaliteli iki boyutlu dedektör dizileri ve konik ışınlı algoritmalarının geliştirilmesi ile KIBT kullanımı daha kabul edilebilir hale gelmiştir ${ }^{8}$.

\section{Kros-seksiyonel Görüntüleme}

Tanı ve tedavi planlaması amacıyla kullanılan kros-seksiyonelden klinik muayene ve radyografik değerlendirme anatomik sınılları (sinirler, damarlar, dişler, kemik korteksi gibi) yeterince gösteremediği za- man ve patolojinin bulunmadığı durumlarda yararlanilır. Önemli anatomik yapılara zarar verme riskini minimalize etmek için ilave bilgi elde edilmesi gereken durumlarda (Konvansiyonel radyografik teknikler kullanıldığında bu bilgi elde edilemiyorsa) kullanıı.ır. Başarıı bir implant tedavisi için mevcut olan kemik yüksekliği ve/veya kemik genişliğinin sınırlı olduğu durumlarda (klinikte sınır vakalarında), implant pozisyonlandırılması ile biyomekanik, fonksiyonel ve estetik olarak tedavi sonuçlarının optimize edilebildiği yerlerde ve cerrahi plak, bilgisayar destekli planlama ve radyografik şablonların kullanımı ile diagnostik bilgilerin geliştirilmesinin gerektiği durumlarda kullaniır ${ }^{13}$.

BT ve KIBT görüntüleme tekniklerinde; 3.0 formunda saklanabilir aksiyel kesitler ve DICOM (Tibbi dijital bilgi haberleşmesi) ile veri toplaması gerçekleştirilmektedir. Diş hekimliği için belirlenen uyumlu bilgisayar yazıımları ile veri işlemesi yapılmaktadır. Kesitsel, panoromik, sefalometrik ve üç boyutlu görüntülere veri yeniden biçimlendirilebilmektedir. Bu görüntüleme tekniklerinde implant tedavi uygulamaları, eşsiz kesitsel görüntüyü ve üç boyutlu yeniden yapılandırmayı sağlamaktadır. İmplant yerleştirilmesi ile cerrahi bölgeye tedavi planlarının transfer edilmesini içeren tedavi planlaması ve tanıya yardımcı olur ${ }^{6}$. BT ve KIBT görüntüleme tekniklerinin özellikleri karşış̧ırımalı olarak Tablo 2' de verilmiştir ${ }^{6,10}$.

Tablo 2. BT ve KIBT Görüntüleme Tekniklerinin Karşılaştıııması

\begin{tabular}{|c|c|c|}
\hline Farklılıklar & KIBT & BT \\
\hline $\begin{array}{l}\text { Radyasyon } \\
\text { ışınının şekli }\end{array}$ & $\begin{array}{l}\text { Paralelleştirilmemiş } \\
\text { Konik biçimde X-ray ışını }\end{array}$ & $\begin{array}{l}\text { Paralelleştirilmiş } \\
\text { Yelpaze biçiminde X-ray ışını }\end{array}$ \\
\hline Hareket tipi & $360^{\circ}$ Tek rotasyon & Çoklu spiral rotasyon \\
\hline $\begin{array}{c}\text { Aletin } \\
\text { büyüklüğüu }\end{array}$ & Küçük (Panoromik gibi) & Büyük \\
\hline $\begin{array}{l}\text { Lokasyon } \\
\text { /yer }\end{array}$ & $\begin{array}{l}\text { Dental ofis/ } \\
\text { Görüntüleme merkezi }\end{array}$ & $\begin{array}{l}\text { Hastane/ } \\
\text { merkezi }\end{array}$ \\
\hline Maliyeti & $\mathrm{Az}$ & Fazla \\
\hline $\begin{array}{l}\text { Hastanın } \\
\text { pozisyonu }\end{array}$ & Oturarak /Ayakta & Supin pozisyonda \\
\hline Tarama zamanı & $10-40 s n$ & $<10$ sn \\
\hline Radyasyon dozu & $\mathrm{Az}$ & Fazla \\
\hline \begin{tabular}{|c|} 
Görüntü \\
kalitesi/ \\
Görüntü \\
çözünürlüğü \\
\end{tabular} & $\begin{array}{l}\text { Voksel boyutu } 0.1 \mathrm{~mm} \\
\text { Sert dokular için iyi } \\
\text { Yumuşak dokular ayırt } \\
\text { edilemez }\end{array}$ & $\begin{array}{l}\text { Voksel boyutu min } 0.5 \mathrm{~mm} \\
\text { Hem sert hem de yumuşak } \\
\text { dokularda gri skalada yüksek } \\
\text { ayırt edilebilirlik }\end{array}$ \\
\hline
\end{tabular}

Oral Radyoloji Avrupa Osseointegrasyon Derneği'ne göre implant yerleştirilecek olan bölge ile doğrudan alakalı olan anatomik yapılar ve sınırlar belirlenmelidir. Harris ve ark $^{7}$ dikkate alınması gerekli anatomik oluşumları: Anterior maxilla'da; burun 
tabanı, nazo-palatin kanal, anterior superior alveoler kanal, Posterior maxilla'da; maksiller sinüs ve ilişkili yapılar, posterior superior alveoler kanal, maksiller tuberosite, pterygoid plakalar, Anterior mandibula'da; lingual foremen, insisiv kanal, genial tüberküller, Posterior mandibula'da; nervus alveoler inferior kanalı, mental foramina, retromolar foremen, sublingual fossa (lingual underkut), mylohyoid undercut, yükselen ramusun lingulası (lingula of ascending ramus) ve Zygomatik bölge'de; orbita tabanı, infraorbital foremen, zygomatik kemik olarak sıralamıştır.

Amerikan Oral ve Maksillofasiyal Radyoloji Derneğinin pre-operatif görüntüleme ile ilgili tavsiyeleri şunlardır:

1. Panoramik radyografi, mandibular implantların diagnostik tetkikinde seçilmesi gereken ilk görüntüleme tekniği olmalıdır.

2. Başlangıç panoromik incelemeyi desteklemek için intraoral periapikal radyografi görüntüleri kullanılmalıdır.

3. Kesitsel görüntüleme, birinci basamak radyografik görüntüleme değerlendirmesi olarak kullanılmamalıdır.

4. Ancak herhangi bir potansiyel implant alanının radyografik değerlendirmesi, ilgilenilen alanın ortogonal kesitsel (kros-seksiyonel) görüntülemesini içermelidir.

5. Potansiyel implant alanının kros-seksiyonel görüntülemesi istendiği zaman, CBCT görüntüleme tekniği seçilmelidir.

6. Sinüs augmentasyon, blok greftleme gibi augmentasyon ve greftleme işlemi planlandığında ilgili bölgenin değerlendirilmesi için CBCT görüntüleme tekniği kullanılmalıdır.

7. CBCT görüntüleme tekniği, implant yerleştirme işlemine hazırlık yapılırken greftleme işlemi ya da augmentasyon yapılmış olan bölgelerin değerlendirilmesinde kullanılmalıdır ${ }^{13}$.

Implant Uygulamalarına İlişkin Komplikasyonlar

İmplant tedavisi yüksek başarı oranları gösteren güvenli bir tedavi seçeneğidir. Bununla birlikte her cerrahi işlemde olduğu gibi bazı komplikasyonlar oluşabilir. Bu komplikasyonların önlenmesi ya da oluştuğunda çözüm bulunması için bilinmesi gerekmektedir $^{5,14}$. Tüm bu klinik komplikasyonları sınıflandırmak zorunludur. Bu yüzden kaza ile komplikasyon kavramları arasındaki ayrımı yapmak gerekir. Kazalar, her za- man cerrahi işlem sırasında meydana gelir. Komplikasyon ise cerrahi işlem yapılır yapılmaz görülmektedir. Ortaya çıktığı zamana göre erken ve geç komplikasyon olarak ikiye ayrılmaktadır ${ }^{14}$.

Oral implant cerrahi uygulamasında kaçınııması gereken sonuçlardan ve başarısızlıklardan birisi komşu yapıların zarar görmesidir. Bu komplikasyonların arasında en önemlileri paranasal sinüsün perfore olması, komşu dişin kökünün zarar görmesi, kortikal tabakanın, damarların, kanalın ve daha da önemlisi sinirlerin perfore edilmesidir. Vakaların çoğunda hatalı implant yerleştirilmesinin nedeni yetersiz tedavi planlamasından kaynaklanmaktadır ${ }^{13}$.

Tarama şablonuna bağlı komplikasyonlar

Cerrahi şablonlar hem implantların tanı ve tedavi planlamasında yardımcı olurken hem de çene kemiği içindeki implantların doğru pozisyon ve açılanma (angulasyon) ile yerleştirilmesini kolaylaştırmaktadır. Cerrahi rehber şablonlar ile gerçekleştirilen restorasyona dayalı implant yerleştirilmesi klinik ve laboratuvar komplikasyonları azaltabilir. Dental implantlara olan talebin artması bu şablonların üretimi için daha yeni ve ileri tekniklerin gelişimine neden olmuştur ${ }^{15}$.

Yararlı bir radyografik stent üretmenin birçok farklı yöntemleri vardır. Farklı klinik durumlara uyum sağlamada klinisyenlerin kullanabileceği radyoopak işaretleyiciler içeren mevcut protezlerin kullanımı, radyoopak işaretleyiciler ile birleştirilmiş termoplastik stent kullanımı, mukoza ya da diş destekli stentte radyoopak dişlerin kullanımı, protez ya da diagnostik wax-up çalışmasının duplike edilmesi ile radyoopak rezin üretimi gibi yaklaşımlar vardır. ${ }^{16}$

Radyografik stentin ideal özellikleri şunlardır; Scatter radyasyona neden olmadan doğru diş formu ve pozisyonunun radyoopak göstergesi olmalı, tutucu ve intraoral olarak stabil olmalı ayn zamanda rahat olmaII, cerrahi rehber olarak kullanılacaksa steril edilebilmeli ve tarayıcı (donanım) platformu ile uyumlu olmalıdir. $^{16}$

Önemli faktörlerden birisi de şablonların doğal destekli ve stabil olmasıdır. Parsiyel dişsizlikte bu durumu sağlamak total dişsizliğe göre daha zordur. Parsiyel dişsizlikte şablon diş (sert) ve mukoza (yumuşak) olmak üzere iki farklı yüzey tarafından desteklenmektedir. İyi bir şablon sadece bir pozisyonda stabil ve rijit olmalıdır ${ }^{17}$.

Dental implantın yerleştirileceği yerin hazırlanması ve implantın yerleştirilmesi için bilgisayar destekli

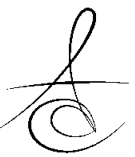


cerrahi sistemlerin kullanımı ile implant pozisyonunun ortalama hassasiyetinin $1 \mathrm{~mm}$ içinde ve implant inklüzyonu (eğim) için sapmanın $5^{\circ}$ içinde olduğu tespit edilmiştir $^{18,19}$.

\section{Nörovasküler yapıların zarar görmesi ile ilgili komplikasyonlar * Nazopalatin kanalın zarar görmesi}

Nazopalatin kanalın morfolojisi ve boyutları aynı zamanda lokalizasyonu ile içeriğinin bilinmesi implant yerleştirilmesi gibi cerrahi işlemler esnasında önemlidir $^{20}$. Dental implantların sinir dokusu ile teması, implantın osseointegrasyonunun olmamasına veya duyusal fonksiyon bozukluğuna neden olabilmektedir ${ }^{21}$. Nazopalatin kanal her bir nazal kavitenin tabanının önüne yakın başlar. Her bir kanal, maksillanın palatin çıııntısının medyan düzlemindeki orta hattaki insisiv foremenin içine açıır ${ }^{20}$.

Dişsiz maksillanın osseointegre implantlar ile rehabilitasyonu için talebin artmasıyla birlikte nazopalatin kanal bölgesinin pre-operatif olarak değerlendirilmesi ve bu kanalın lokalizasyonu ile ilişkin zorluklar ve anatomik sınırlayıcılar tanımlanmalıdır. Diş kaybından sonra kullanılmama atrofisi çevreleyen yapıları etkileyebilir $^{20}$. Premaksiller bölgede diş çekiminden sonra kemik kaybının ilerlemesi ile alveoler kret, anatomik yapılara yaklaşabilir. Bu durum implant yerleştirilmesini ve protezin tutuculuğunu zorlaştırmaktadır. Maksillanın anterior alveollerinin palatal migrasyonu ile nazopalatin sinir ve damarlar kret tepesinden çıkmaktadır. Bununla birlikte nazopalatin kanal statik yapıda değildir ve genişleme eğilimindedir ${ }^{22}$.

Nazopalatin kanalın değişiklikleri veya morfolojik farklılıkları kompleks bir restorasyonda problem olmaya devam etmektedir ${ }^{20}$. Hem üst hem de alt çenede anterior bölgede implant cerrahisini gerçekleştirmeden önce nörovasküler demetlerin varlığını ve kesin olarak yerini saptamak son derece önemlidir ${ }^{23}$. Jacobs ve $a^{23}{ }^{23}$ yüksek çözünürlükte manyetik rezonans görüntülemenin nörovasküler yapıların mikro-anatomisini değerlendirmede alternatif bir teknik olduğunu bildirmişlerdir. Bu tekniğin başlıca avantajı histolojik kesit ve boyama gereksinimi olmadan doku yapılarının mikroskobik seviyede incelenebilmesidir ${ }^{23}$.

\section{* Lingual vasküler kanalların zedelenmesi}

Mandibular anterior bölgedeki dental implant cerrahisinin nispeten güvenli ve basit olduğu düşünülmektedir $^{24}$. Bununla birlikte son zamanlarda dental implant cerrahisinde mandibulanın lingual yüzeyindeki kortikal kemiğin perforasyonu ile anterior bölgeyi besleyen damarların zarar gördüğü bildirilmiştir. Ağız tabanındaki arterlerin zarar görmesi ile oluşan kanama komplikasyonu anatomik olarak yakınlık ile ilgili olup cerrahi ile ilişkili değildir. Bu yaralanmaların neden olduğu kanama nadir olarak solunum yolu tıkanmasına ve ölümcül komplikasyona neden olabilir ${ }^{25}$. Bu nedenle lingual arter ve dallarının ağız tabanındaki anatomisinin bilinmesi önemlidir ${ }^{26}$.

Lingual arter hyoid kemiğin büyük boynuzunun hizasında eksternal karotid arterden ayrıldıktan sonra hiyoglossus kasının altından geçerek sublingual kompartmana ulaşır. Dilin parankimine derin lingual arter olarak katılmadan önce sublingual ve hyoid dallarına ayrılır. Sublingual arter sublingual bez, ağız tabanı mukozası ve mylohyoid kasını beslemesinin yanı sıra medial mandibular dalını vererek mandibular korteksin anterior ve lateral yüzeylerini de beslemektedir ${ }^{26}$.

Dental BT görüntüleme yöntemi çenelerin anatomik ve patolojik yapılarını ve özellikle lingual foremeni gösterebilmektedir. Bu foraminaların varlığının panoromik radyografiler kullanılarak görselleştirilmesi olanaksızdır. Mandibulanın konumu ile bu foraminalar medial lingual foremen ve lateral lingual foramen olarak iki gruba ayrılmaktadı ${ }^{25}$. Tagaya ve ark $^{25}$ yaptıkları çalışmada medial lingual foremenin görülme sıklığının $\% 100$ ve lateral lingual foremende ise bu sıklığın \% 80 olduğunu bildirmişlerdir.

Gültekin ve $\operatorname{ark}^{26}$ yaptıkları bir çalışmada mandibuladaki lingual vasküler kanalların sayısı, boyutları, yerleşim ve doğrultularının saptanmasında BT'nin duyarlılığını araştırmışlardır. Alt çene dental implant yerleştirilmesi öncesi dental BT incelemesi yapılan 26 hasta çalışmaya dahil edilmiştir. Hastaların hepsinde en azından bir lingual kanal, 8 hastada (\%31) en az iki lingual kanal bulunmuştur. İki hastada dört kanal tespit edilmiştir. Tipik lingual kanal lokalizasyonları mandibula orta hattı ve premolar bölgeler olduğunu ve lingual kanalların ortalama çaplarının orta hatta $0.8 \pm 0.2 \mathrm{~mm}$, premolar düzeylerde $0.6 \pm 0.1 \mathrm{~mm}$ olduğunu bildirmişlerdir. Dental BT ile mandibular lingual vasküler kanalların sayısı, boyutları, yerleşim ve doğrultularının başarılı bir şekilde saptandığını, diş hekimlerinin bu kanallar ve önemleri konusunda yeterli bilgi sahibi olmaları ile dental implant uygulaması sırasında olabilecek ciddi kanama komplikasyonlarının azaltılabileceği sonucuna ulaşmışlardır. 


\section{* Inferior alveolar sinirin zarar görmesi}

Mandibular implant cerrahisinde en önemli ve ciddi komplikasyonlardan birisi inferior alveoler sinirin zedelenmesidir $^{27,28}$. Bu nedenle implant yerleştirilecek bölgede mandibular kanalın yönünün lokalize edilmesi önemlidir ${ }^{27}$.

Dental implantla ilişkili olan sinir yaralanmaları kalıcı olabilir ve hastaların yaşam kalitesini değiştirmektedir. Dental implant tedavisi doğal ve elektif (seçmeli) bir işlemdir. Bu nedenle sinir yaralanmalarından kaçınılabilinir. Sinir yaralanması oluştuğunda klinisyenin inmalinin söz konusu olduğu düşünülebilir ve adli sonuçları doğurabilir. İmplant tedavisine başlanılmadan önce gerekli olan bütün zorunlu aşamalar; pre-operatif planlama yapılması, hasta beklentilerinin karşılanması ve aydınlatılmış onam formunun alınması işlemleridir. Kalıcı sinir zedelenmeleri rektifiye edilemez (giderilemez). Bu nedenle hasar oluşması önlenmeli$\operatorname{dir}^{13}$.

İnferior alveoler sinirin yaralanmasından kaçınmak için inferior alveoler sinirin doğru lokalizasyonu ve inferior alveoler sinir kanalının koronalindeki mevcut kemiğin doğru ölçümü yapılmalıdır. BT esaslı cerrahi stentler ya da navigasyon sistemleri sinir yaralanmasını önlemede yardımcı olabilir ${ }^{29}$.

Vazquez ve ark $^{27}$ yaptıkları çalışmada operasyon öncesi görüntüleme tekniği olarak sadece panoromik radyografi kullanıldığında mandibular posterior bölgeye implant yerleştirilmesi sonrası mental sinir zedelenmesine bağı duyu değişimi oranını değerlendirmişlerdir. Bu çalışmada 1527 kısmi ya da total dişsiz hastaya mandibular posterior bölgede 2584 implant yerleştirilmiştir. Alveoler kretin üst sınırından mandibular kanalın üst sınırına kadar standart panoromik radyografide operasyon öncesi kemik yüksekliği değerlendirilmiştir. Bütün radyograflar görüntüleme kutusunda standart şartlar altında implant firmasının skalası kullanılarak analiz edilmiştir ve $2 \mathrm{~mm}$ güvenlik payı olarak çıkartılarak yerleştirilecek implantın uzunluğunu belirlemişlerdir. İnferior alveoler sinir zedelenmesine bağlı kalıcı duyusal bozukluk gözlenmemiştir. Hastalarda \%0.13 oranında post-operatif parestezi olduğu ve bu duyusal bozuklukların 3 ve 6 hafta sonra kendiliğinden iyileştiği sonucuna ulaşmışlardır.

Kütük ve $a^{2}{ }^{28}$ yaptıkları bir retrospektif klinik çaIışmada panoromik görüntüleme tekniğinin implant ile mandibular kanalın yakınlığının $2 \mathrm{~mm}$ 'den az olan hastalarda mandibular posterior bölgeye implant yerleştirilmesi ile duyusal sinir bozukluğu (nörosensoriyel bozukluk) komplikasyonunun görülme riskini değerlendirmişlerdir. 1957 hastanın ve 3608 dental implantın panoromik görüntüsünü incelemişler ve 48 implantın mandibular kanala $2 \mathrm{~mm}$ 'den daha (0-1.9 mm) yakın olduğu iki boyutlu bilgisayar yazılım programı kullanılarak belirlenmiştir. 14 implant mandibular kanala 1 mm'den daha yakın ve 34 implant ise mandibular kanala uzaklığı 1-2 mm arasında yerleştirilmiştir. Sadece bir hastada geçici nörosensoriyel bozukluk tespit edilmiştir. Nörosensoriyel komplikasyonları önlemek için panoromik radyografi kullanılarak implant uzunluğunun belirlenmesinin güvenilir bir teknik olduğu, BT ya da KIBT tekniği ile dental implantların planlamasının yapılmasının sınır vakalarında gerekli olabileceği sonucuna ulaşmışlardır.

\section{* Mandibular kanalın anterior loop bölgesindeki zedelenme}

Dental implant cerrahisi sırasında komplikasyonlardan kaçınmak için mental foramenin pozisyonunun radyografik olarak belirlenmesi yeterli değildir. Vakaların çoğunda inferior alveoler sinir 'anterior loop' adı verilen şekilde mesial olarak uzanmaktadır ${ }^{30}$.

Gómez-Román ve ark $^{30}$ yaptıkları çalışmada BT tekniği ile anterior loop'un ( $A L$ ) bulunma sıklığı ve uzunluğunu araştırmışlardır. 37 insan mandibulasında BT analizi yapılarak kros-seksiyonel ve panoromik görüntüler elde edilmiştir. BT görüntüde AL'nin tanınmasının \%100 olduğunu, görülme sıklığının \%97.3 ve ortalama uzunluğunun $2.26 \mathrm{~mm}$ olduğunu bildirmişlerdir. BT taramasında AL'nin tanınması (\%100) panoromik radyografi (\%38.2) ile karşılaştırıldığında daha yüksek olduğunu, AL varlığı ve mental foramenden mesial genişlemesinin belirlenmesinin komplikasyonlardan kaçınmak için önemli olduğu, AL'nin mesial uzantısından en az $2 \mathrm{~mm}$ güvenlik mesafesinin olması gerektiği sonucuna ulaşmışlardır.

\section{* Lingual sinir zedelenmesi}

Lingual sinir zedelenmesi, dental implant yerleştirilmesi sonrasında görülen yaygın bir komplikasyondur. Sinir zedelenmesinin derecesine bağlı olarak bu komplikasyon hissizlik, parestezi, anestezi, analjezi, hiperestezi, hiperaljezi ve allodini gibi çeşitli duyu bozukluklarına neden olabilir. Bu gibi durumlar nöropatik ağrı olarak kabul edilmektedir ${ }^{31}$.

\section{* Infraorbital sinir zedelenmesi}

İnfraorbital sinir, trigeminal sinirin ikinci dalı olan maksiller sinirin bir dalıdır. İnfraorbital sinir orta yüz mukozası ve deriyi beslemektedir. İnfraorbital foramen 
yoluyla yüze ulaştığında infraorbital sinir, üç alveoler proksimal dallarına (anterior, middle ve posterior superior sinir) ve dört distal dallarına (inferior palpebral, external nasal, internal nasal ve superior labial) ayrllir ${ }^{21}$.

İnfraorbital kanal, anterior superior alveoler (ASA) sinirin geçişine izin veren lateral bir dal verir. Bu dal canalis sinuosus (CS) olarak adlandırılır ${ }^{32}$. Canalis sinuosus, ASA sinirinin anatomik bir varyasyonudur ${ }^{21}$. CS, orbitanın alt duvarından aşağıya doğru, maksiller sinüsün ön duvarından medial olarak uzanır ve infraorbital foramenin altından geçer. Nazal fossanın lateral ve alt sınırlarını geçerek nazopalatin kanalın önünde nazal septumun lateraline açlır. Nazal fossa lateral duvarına ulaşıı̆ında CS aniden aşağıya doğru döner. Nazal kavite, kesici ve kanin dişlerin alveollerinin medial yüzleri arasında yer alır. Bu kısımda kanin dişine doğru ilk dental dalını ve kesici dişlere doğru küçük dallarını veriir ${ }^{32}$.

CS, anterior superior alveoler sinir, damarları ve ilgili arterleri içeren nörovasküler bir kanaldır ${ }^{21,32}$. Bu kanal, diagnostik görüntüleme incelemelerinde yetersiz olarak tanınmaktadır. Bununla birlikte cerrahi işlem sırasında ve sonrasında önemlidir. CS kanalının varlığından habersiz olan diş hekimlerinin çoğu, rutin panoromik ve periapikal radyografilerde üst kesici ve kanin bölgesindeki periapikal bir radyolusensi olarak tanımlanan CS kanalı bazen yanlışlıkla bir patolojik lezyon olarak yorumlayabilmektedirler ${ }^{32}$.

Maksiller anterior bölgeye dental implant cerrahisi estetik, fonetik ve biyomekanik gereksinimleri karşlamak ile birlikte anatomik sınırlamalar nedeniyle çoğu zaman zordur ${ }^{21}$. Cerrahi öncesi muayene sırasında bu bölgeye dental implant planlanırken nazopalatin kanal, insisive foramen ve nazopalatin sinir gibi bazı anatomik yapılar sınırlayıcı olarak kabul edilmektedir. Bununla birlikte ASA siniri ve CS kanalın varlığı gibi nörovasküler demetler anterosuperior dişlerin köklerine yakın bir şekilde gözlemlenebilmektedir. Bu anatomik ilişki nedeniyle dental implant planlaması sırasında ayrıntıı radyografik inceleme gereklidir ${ }^{32}$.

Neves ve $\mathrm{ark}^{21}$ yaptıkları çalışmada pre-operatif olarak KIBT görüntülerinde anatomik varyasyonları (canalis sinuosus) belirlemişler ve aksesuar nörovasküler demetlerin yaralanmasından kaçınmak için dikkatli bir şekilde implantları yerleştirmişlerdir. Cerrahiden sonra hastanın takip randevusunda herhangi bir komplikasyon oluşmadığını bildirmişlerdir.
KIBT görüntüleme tekniği, iki boyutlu incelemeler ile karşılaştırıldığında daha güvenilir ve tekrarlanabilir yüksek çözünürlükte görüntü oluşmasını sağlar. Bu teknoloji ile daha ince kesit kalınlığı ile görüntüler oluşur ve kemik yapıların iyi bir şekilde görselleştirilmesini sağlar ${ }^{32}$. Özellikle daha küçük voksel boyutu kulanıIırsa KIBT tekniği ile bilgisayar görüntülerinde canalis sinuosos gibi anatomik varyasyonların farkedilmesi mümkündür. Bireysel anatomik varyasyonların KIBT tekniği ile belirlenmesi implant yerleştirilmesi sırasında sinirlerin yaralanmasından kaçınmak için cerraha yardımcı olacaktır ${ }^{21}$.

\section{Nöropatik Ağrı}

İmplant yerleştirilmesi ile ilişkili olarak görülen nöropatik ağrı nadir görülen bir komplikasyondur. Literatürlerde, sinir ile ilgili komplikasyonlar ağırıklı olarak 'duyusal bozukluklar' olarak sınflandırımaktadır. Parestezi ve disestezi oluşumu üzerinde durulmaktadır $^{33}$.

Leckel ve $a^{33}{ }^{33}$ yaptıkları bir vaka sunumunda 56 yaşındaki sistemik olarak sağlıklı erkek hastaya mandibular sol posterior bölgeye operasyon öncesi panoromik radyografi alınarak iki adet implant yerleştirilmiştir ve cerrahiden bir hafta sonra sol mandibular premolar bölgede devamlı yanma ağrısı başladığı disestezi ya da anestezi olmadığı hasta tarafından bildirilmiştir. Konvansiyonel radyografi ile (panoromik, apikal dental $x$-ray) mandibular kanalın ana hatlarının implant apeksine yakınlığını belirleyememiştir. Karbamazepin ile farmakolojik tedavi hastanın ağrısının yoğunluğunu biraz azaltmıştır. BT görüntüleme tekniği ile mandibular kanalın kemik yapıları ve implant apeksine yakınlı̆ı belirlenmiştir. Yüksek çözünürlüklü manyetik rezonans görüntüleme (MRG) tekniği kullanılarak nervus alveolaris inferior üzerindeki fonksiyonel etkisi gösterilmektedir. Neden olan implant çıkartıldıktan sonra hastanın ağıısı yavaş bir şekilde azalmıştır ve 1 yıl sonra ağrısı kalmamıştır.

\section{Nörosensoriyel bozukluklar}

Mandibular posterior bölgede dental implant yerleştirilmesi esnasında nervus alveolaris inferior zedelenmesinin bir sonucu olarak nörosensoriyel bozukluklar gelişebilmektedir. Bu komplikasyon hafif paresteziden tam anesteziye kadar görülebilen en rahatsız edici deneyimlerden birisidir $^{28}$.

DuToit ve ark $^{13}$ tarafindan yaralanma durumlarında sinir semptomlarının tanımlamaları Tablo 3'teki gibi gruplandırımışır. 
Tablo 3. Sinir Semptomlarının Tanımlamaları

\begin{tabular}{|c|c|}
\hline Anestezi & Uyuşukluk, muayenede hiç bir duyu algısı yok \\
\hline Allodini & Bir uyarıııdan kaynaklanan ağrı, genellikle ağrı ile ilişkili değil \\
\hline Hiperaljezi & Acı veren bir uyarandan (stimulus) kaynaklanan abartılmı̧ ağrı \\
\hline Parestezi & Değişmiş duyu hissi, karıncalanma, batma ve iğneleme hissi \\
\hline Disestezi & Rahatsız edici bir değişmiş duyu hissi \\
\hline
\end{tabular}

\section{Maksiller sinüs}

Dişsiz posterior maksiller bölgenin dental implantlar ile rehabilitasyonunda karşılaşılan sık sorunlardan birisi önerilen implant bölgesinin yeterli kemik hacmine sahip olup olmadığıdır ${ }^{34}$. Bu bölgedeki kemik hacmi; maksiller sinüsün varlığı, maksiller sinüsün sürekli pnömatizasyonu ve alveoler kemik yüksekliğinin ilerleyen (progresif) rezorpsiyonu ile sınırlandırılmaktadır ${ }^{1}$.

Posterior maksiller bölgede azalmış vertikal kemik yüksekliğini kompanse etmek için öngörülebilir ve en etkili yollardan birisi maksiller sinüs elevasyon tekniğidir $^{35,36}$. Sinüs tabanını artırmak için çeşitli cerrahi teknikler geliştirilmiştir. Uygulanan teknik ne olursa olsun, enfeksiyon, greft başarısızığı ve sinüs membran perforasyonu gibi cerrahi sonrası komplikasyonlar cerrahi işlemin başarısızlığına neden olabilir. Cerrahi başarısızlık, önceden var olan sinüs hastalığı ya da sinüs hastalığına yatkınlık ile ilişkili olabilir. Bu nedenle augmentasyon işlemi öncesinde maksiller sinüslerin doğru bir şekilde pre-operatif değerlendirilmesi, post-operatif komplikasyonları en aza indirmek ve işlemin başarı oranını artırmak için gereklidir ${ }^{34}$.

Maksiller sinüsü incelemek için birçok radyografik görüntüleme tekniği kullanılmaktadır ${ }^{34,37,38}$. Panoromik radyografi, Avrupa Osseointegrasyon Derneğine göre üst çenede implant yerleştirilmesinde en yaygın kullanılan tetkiktir ${ }^{39}$. Bununla birlikte panoromik radyografilerin görüntü tabakası boyunca oluşan geometrik distorsiyonu ve eşit olmayan magnifikasyonu gibi doğal sınırlamaları bulunmaktadır. Bu durum anatomi ve patolojinin yanlış yorumlanmasına ayrıca yapılan ölçümlerin güvenli olmamasına neden olmaktadır. Bazen servikal omurga gibi üst üste çakışan yapıların varlığı yanlış tanıya neden olabilmektedir ${ }^{34}$. Maksiller sinüsün medial duvarı ile ilişkili patolojiler panoromik radyografide sık olarak görülememektedir. $\mathrm{Bu}$ nedenle panoromik radyografiler sinüs patolojilerinin belirlenmesinde güvenilir bir yöntem değildir ${ }^{37}$.

Maksiller sinüsün üç boyutlu olarak değerlendirilmesi, maksiller sinüsün detaylı olarak incelenmesine imkan tanır. Sinüs tabanı ile birlikte sinüsün medial ve lateral duvarlarının yeterli görüntüsü sağlandığı için sinüsün bütün anatomik sınırları görülür ve komplikasyon riski azalmaktadır ${ }^{34}$.

İmplant tedavisi öncesinde maksiller sinüsün mukozal kalınlaşması ve patolojisinin değerlendirilmesi çok önemlidir. Sinüs lift ve greft işlemi kullanarak sinüs augmentasyon işleminin ne zaman yapılması gerektiği, herhangi bir cerrahi augmentasyon işlemi gerçekleştirmeden ne zaman kaçınılması gerektiği ve Kulak Burun Boğaz (KBB) doktoru ile konsültasyon yapılmasına karar vermede klinisyene yardımcı olabilecek bir sınıflandırma önerilmektedir ${ }^{34}$. (Tablo 4)

Tablo 4. Maksiller sinüsteki mukozal kalınlaşma ile ilgili sinüs tabanının yükseltilmesi (sinüs augmentasyonu) işlemleri için önerilen sınıflandırma

\begin{tabular}{|c|c|c|}
\hline & Mukozal kalınlaşma & Tavsiye \\
\hline $\begin{array}{c}\text { Klas } \\
1\end{array}$ & 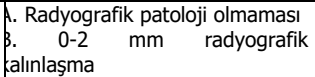 & $\begin{array}{l}\text { Sinüs tabanının yükseltilmesi muhtemel } \\
\text { herhangi bir komplikasyon riski olmadan } \\
\text { yapılabilir. }\end{array}$ \\
\hline \begin{tabular}{|c|} 
Klas \\
2
\end{tabular} & -5 mm radyografik kalınlaşma & $\begin{array}{l}\text { Sinüs tabanının yükseltilmesi yapılabilir, } \\
\text { dikkatli olunmalıdır. }\end{array}$ \\
\hline $\begin{array}{c}\text { Klas } \\
3\end{array}$ & $\begin{array}{l}\text {-9 mm radyografik kalınlaşma } \\
\text { Maksiller sinüsün kısmi oblite- } \\
\text { asyonu olan ya da olmayan }\end{array}$ & $\begin{array}{l}\text { Sinüs tabanının yükseltilmesi yapılması } \\
\text { kontrendike } \\
\text { KBB doktoru ile konsültasyon yapılmalı. }\end{array}$ \\
\hline Klas & $\begin{array}{l}\text { 9mm maksiller sinüsün kısmi de } \\
\text { lahil olmak üzere total } \\
\text { pbliterasyonu }\end{array}$ & $\begin{array}{l}\text { Sinüs tabanının yükseltilmesi yapılması } \\
\text { kontrendike } \\
\text { KBB doktoru ile konsültasyon yapılmalı. }\end{array}$ \\
\hline
\end{tabular}

Tadinada ve $\operatorname{ark}^{34}$, KIBT görüntüleme tekniği kullanılarak maksiller sinüsün üç boyutlu olarak görüntülenmesinin sinüs patolojilerinin tespit edilmesinde panoromik radyografi ile karşılaştırıldığında anlamlı olarak daha fazla güvenilir olduğunu bildirmişlerdir.

\section{Postoperatif maxiller sinüzit}

Sinüzit aseptik cerrahi koşullarda oral flora ile maksiller sinüsün kontaminasyonunun bir sonucu olarak meydana gelebilmektedir. Sağlıklı bireylerde cerrahi işlem esnasında iyatrojenik küçük sinüs membran perforasyonları post-operatif sinüzit gelişimi ile ilişkili görünmemesine karşın maksiller sinüs membranının büyük perforasyonlarında maksiller sinüs içine kemik parçalarının boşalması ve maksiller sinüzite neden olma olasılığı daha yüksektir. Post-operatif olarak maksiller mukozanın şişmesi nedeniyle ostium tıkanıklığı, azalan sinüs içi hacmi nedeniyle hava akımının tıkanması, mukozal laserasyonlar ve implanta maruz kalma nedeniyle maksiller sinüsteki bozulmuş mukozal aktivite diğer nedenler arasındadır ${ }^{1}$.

\section{Burun tabanı perforasyonu}

İmplantların gelişimi ile birlikte ortodontik tedavide iskeletsel ankraj sağlamak için palatinal bölgeye mini-implant uygulanmaktadır. Palatinal bölgeye mini-

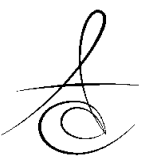


implant yerleştirilmeden önce nasal kavite perforasyonları ve insisiv foremen yaralanmaları gibi komplikasyonları önlemek için doğru planlama yapılması gerekir $^{40}$. Burun tabanının perforasyonu veya yeterli kemiğin olmaması gibi daha fazla komplikasyon riski taşıyan hastaların operasyon öncesinde belirlenmesi önemlidir ${ }^{41}$.

de Rezende Barbosa ve ark $^{40}$ yaptıkları bir çalışmada palatinal bölgeye mini-implant yerleştirilmesinin planlanmasını yapmak için birinci premolar bölgesinde palatinal kemik yüksekliği ölçümlerini konvansiyonel lateral radyografi (CLR), konik ışınlı bilgisayarlı tomografi (KIBT) ve yeniden biçimlendirilmiş sanal lateral radyografi (VLR) tekniklerini kullanarak karşılaşıımışlardır. 110 hastanın üst birinci premolar bölgesinde mevcut kemiğin boyutları ile ilgili lineer ölçümler, sert damak tabanı ve burun tabanı arasında gerçekleştirilmiştir. Bütün radyografik tekniklerin ölçümleri Friedman testi kullanılarak karşılaştırılmıştır. VLR tekniği ile yapılan ölçümlerin KIBT ve CLR tekniğinden istatistiksel olarak farkllık gösterdiğini bununla birlikte CLR tekniğinin değerlerinin ise, KIBT görüntülerinden istatistiksel olarak anlamlı fark göstermediği sonucuna ulaşmışlardır.

\section{perforasyonu}

Bukkal ya da lingual kortikal tabakaların

Mandibular posterior bölgede osteotomi hazırlığı sırasında lingual tabakanın perforasyon riskini artırdığı için lingual konkavitenin varığı özel bir dikkat gerektirmektedir ${ }^{42}$. Chan ve ark ${ }^{42}$ kret şeklini ve potansiyel perforasyon riskini belirlemek için kretleri $U$ (undercut), C (konverjent/yaklaşan) ve $\mathrm{P}$ (paralel) olmak üzere üç tip olarak sınıflandırmışlardır ve yaptıkları çalışmada bu kret şekillerinin görülme oranlarının sırasıyla \%13.6, \%20.4 ve \%66 olduğunu bildirmişlerdir.

\section{İnter aktif İmplant Tedavi Planlaması}

İmplant yerleştirilmesinde protetik uygulamaların felsefesi, implantın diş hekimliğinde nasıl uygulanacağı konusunda yeni bir çığır açmışır. Mevcut kemiğin yüksek olan bölgesine implant yerleştirmesi fikri geçerliliğini kaybetmiştir. Yeni bakış açısı implant diagnoz ve tedavi planlamasına fonksiyonel, estetik ve protetik uygulamaların hepsinin dahil edilmesidir. Protetik tasarımlar, dental implantların pozisyonlarını belirlemektedir 6 . Bu amacı gerçekleştirmek için BT görüntüleme yardımı ile model destekli tedavi planlaması geliştirilmiştir $^{43}$. Tanı modelleri döküldükten ve planla- ma öncesi wax-up çalışması yapıldıktan sonra diagnostik şablonlar hazırlanmaktadır ya da hastanın mevcut protezi modifiye edilmektedir. Belli noktaları işaretlemek için metal pinler ya da gutta-percha gibi radyoopak materyaller kullanılarak final restorasyon pozisyonuna dayalı yerleştirilecek implantın pozisyonu ve yönü belirlenmektedir. Daha sonra görüntülemede mevcut kemik yüksekliği, genişliği ve ilişkili anatomik yapılar değerlendirilmelidir. Bu elde edilen bilgilere göre nihai implant pozisyonunun belirlenmesinde değişiklikler yapllabilmektedir. İkinci bir rehber, değişikliklere göre manuel olarak üretilebilmektedir ya da bu stent operasyon esnasında cerrahi rehber olarak kullanılabilmektedir. Bu yaklaşım, başarıı bir teknik olarak gösterilmiştir ${ }^{6}$.

\section{Bilgisayar destekli implant planlaması}

Günümüzde implant cerrahisini kolaylaştırmak ve optimize etmek için çeşitli bilgisayar destekli sistemler mevcuttur ${ }^{44}$. Planlanmış bilgileri klinik duruma transfer etmede farklı yöntemler kullanılmaktadır ${ }^{45}$. Jung ve ark ${ }^{46}$ bu yöntemleri statik ve dinamik olarak kategorize etmişlerdir. Statik yöntemler, cerrahi şablonlar ya da implant rehberleridir. Dinamik sistemler ise, seçilen implant pozisyonunu cerrahi alana bir monitörde görsel görüntüleme araçları yardımıyla transfer etmektedir. Dinamik sistem cerrahi navigasyon ve bilgisayar destekli navigasyon teknolojilerini içermektedir ve cerrahın gerçek (eş) zamanlı olarak implant konumunu değiştirmesine izin vermektedir ${ }^{45}$. (Tablo 5)

Tablo V. Statik ve dinamik rehberli cerrahinin çalışma prensibi

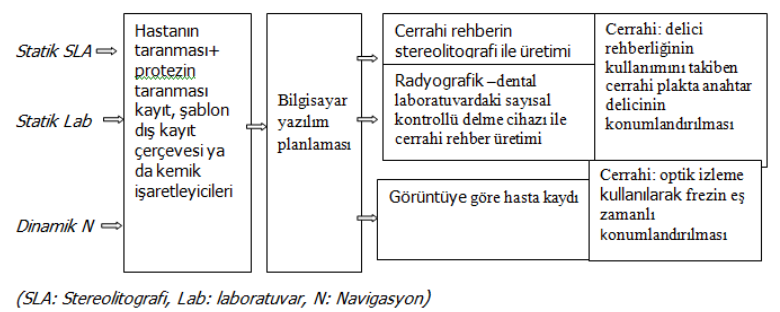

Bilgisayar rehberli (statik) implant cerrahisi, bilgisayarlı tomografik veriden elde edilen sanal bir implant cerrahi planı üreten statik bir cerrahi şablonun kullanılması olarak tanımlanmaktadır ve implant pozisyonunun intraoperatif değişikliklerine izin vermez ${ }^{46}$. Bilgisayar rehberli cerrahinin avantajı, sanal bir implant planlama yazılım programındaki protetik tedavi planlama sürecine dayalı bilgisayar destekli tasarım ve bilgi- 
sayar destekli üretim (CAD/CAM) tekniğiyle üretilen cerrahi şablon ile implant yerleştirmenin daha öngörülebilir olmasıdır. Geleneksel döküm destekli implant planlaması ve cerrahi şablon üretimi, planlama sürecinde aynı anda tüm protetik ve anatomik parametrelerin görselleştirilmesine izin vermez. Elde edilen cerrahi şablon implant yerleştirilmesi sırasında tam olarak üç boyutlu rehberlik sağlayamaz. Bilgisayar rehberli implant cerrahisi için mevcut sistemlerin çoğu benzer bir tedavi protokolüne sahiptir. İşaretleyiciler ile birlikte radyografik şablon istenilen protetik tedavi planını gösterir. Radyografik şablonu takan hastaya KIBT tekniği uygulanır. Elde edilen KIBT verileri, protetik esaslı bir implant cerrahi planı formüle edilmesi için sanal implant planlama yazılım programına aktarılır ${ }^{47}$.

Dinamik sistemler, preoperatif planlama ve BT taramalarından elde edilen anatomik bilgileri kullanarak gerçek zamanlı implant pozisyonu ve cerrahi işlemi değiştirebilme olanağı sunar. Cerrahi navigasyon sistemleri, hem hastaya hem de cerrahi el aletine bağlı sensörler gerektirir. Bu sensörler üç boyutlu pozisyon bilgisini kamera ya da detektöre iletir. Bilgisayarda hemen planlama yapılır ve hastanın anatomisinin depolanmış görüntüsüne göre aletlerin sanal pozisyonunu gösterir ${ }^{46}$.

Bilgisayar rehberli navigasyon sistemlerinin doğruluğu; cerrahi planlamadan veri aktarımına, cerrahın sistemle etkileşim yeteneğine, monitör göstergelerine dikkat edilmemesine ve teknik başarısızlıklar gibi birçok faktör tarafından kontrol edilmektedir. Bu faktörlerin üzerinde iyi bir kontrol mekanizması, manuel implantasyon üzerine bilgisayar destekli navigasyonu yükler. BT kullanımı ile ilgili tek dezavantaj daha fazla radyasyona maruz kalınmasıdır. Bu dezavantajın üstesinden gelebilmek için çeşitli çalışmalar yapılmaktadır ${ }^{8}$.

Rehberli implant cerrahisi, serbest el cerrahisi ile karşılaştırıldığında ağızdaki implantın son pozisyonu ile planlanmış pozisyonu arasındaki sapma olarak tanımlanan hatayı azaltmaktadır. Rehberli implant cerrahisi; kompleks anatomide, minimal invaziv cerrahi gerektiğinde, implant yerleştirilmesini optimize etmek gerektiğinde (kritik estetik vakalarda) ve immediat yüklemede klinik olarak endikedir ${ }^{44}$. Bu yaklaşım geriatrik hastalarda ve medikal durumu riskli olan hastalarda faydalıdır. Sadece bilgisayar destekli planlamanın kullanılması hem hastaya hem de klinisyene fayda sağlamaktadır ${ }^{45}$.
Uygun bir yazılım programı kullanarak implant planlama verisinin cerrahi alana transfer edilmesi en zor kısmıdır ${ }^{44,45}$. Digital teknoloji hızlı bir şekilde gelişmektedir ve yeni gelişmeler hataların azaltılmasına olanak sağlayacaktır. Hastanın pre-operatif muayenesinden rehberli cerrahinin uygulanmasına kadar gerekli olan aşamaların sayısını azaltmak önemli bir yaklaşımdır. Üç boyutlu radyografik veri ve üç boyutlu yazılım ile optik taramanın birlikte uygulanması bu durumu mümkün kılmaktadır ${ }^{44}$.

Cerrahi rehberler mukoza, diş, kemik ${ }^{48}$ ya da geçici implantlar tarafından desteklenebilirler. Bütün bu durumlarda ilave stabilizasyon kemik tutucu vidalar ya da pinler ile sağlanabilmektedir ${ }^{44}$. Diş destekli cerrahi plaklar, işlemde en yüksek doğruluğu sunmaktadır $^{48}$. Mukoza destekli cerrahi plak işlemleri kemik destekli olanlar ile karşılaştırıldığında daha yüksek doğruluk göstermektedir ${ }^{49}$. Maksilla ile mandibulanın rehberli cerrahisinin doğruluğu karşılaştırıldığında önemli bir farklılık gözlenmemiştir ${ }^{45}$. Geçici implantlar kullanıldığında tarama yapılacak protezin ve cerrahi plağın stabilizasyonu cerrahi işlemlerin daha doğru gerçekleştirilmesine neden olur. Cerrahi rehberler konvansiyonel olarak ya da hızlı prototipleme teknikleri ile üretilebilmektedir $^{44}$.

\section{CAD/CAM esaslı cerrahi rehberler}

CAD/CAM teknolojisi, implant ile rehabilitasyonda planlama yapmak için BT taramalarından elde edilen veriyi kullanır. BT görüntülerini, BT görüntüleme ve planlama yazılımı ile tanınan veriye dönüştürür. Daha sonra bu yazılım cerrahi öncesi yapılan planlamayı stereolitografik delici kılavuzların kullanımı ile cerrahi alana transfer eder. CAD/CAM esaslı cerrahi rehberlerin kemik morfolojisinin sanal üç boyutlu görüntüsü ile cerraha implant yerleştirilmesinden önce cerrahi kemik alanının görselleştirilmesine imkan vermesi, yetersiz kemik desteği veya önemli anatomik yapıları tehlikeye atma gibi risklerden kaçınılması, tarama şablonu kullanılması ile protetik planlamanın birleştirilmesi tedavinin protetik ve biyomekanik açıdan optimize edilmesine olanak sağlaması, bu tekniğin flep kaldırmadan yapılan cerrahi işlemi teşvik etmesi ve cerrahi öncesi ana dökümün ve geçici restorasyonların yapılmasına imkan vermesi ayrıca immediat yüklemeye olanak tanıması gibi bir çok olumlu özellikleri bulunmaktadır $^{15}$.

Dental implant planlamasında ve cerrahiden önce yapılan planlamanın cerrahi bölgeye tahmin 
edilebilir transferinde CAD/CAM teknolojisinin doğruluğu belgelenmiştir ${ }^{15,50}$. Doğruluk, yazılım programındaki planlanmış implant pozisyonu ile hastanın ağzındaki implantın gerçek pozisyonunun eşleştirilmesi olarak tanımlanmaktadır. İmplant veya osteotomi bölgesinin doğruluğu; giriş noktasındaki sapma, apeksteki sapma, uzun eksen sapması ve derinlikteki/yükseklikteki sapma olmak üzere çoğunlukla dört parametre ile ifade edilmektedir. Planlanmış ile yerleştirilmiş implant pozisyonunun eşleştirilmesi ikinci bir KIBT taraması veya model eşleştirilmesi (pre-operatif ve post-operatif modellerin karşılaştırılması) ile yapılabilmektedir ${ }^{45,51}$.

CAD/CAM teknolojisi ile üretilen cerrahi rehberlerin etkinliği ile ilgili daha fazla çalışmaya intiyaç vardır $^{15}$. Rehberli implant yerleştirilmesinin etkinliği, implantın sağ kalım ya da başarı oranın belirlemektir. Rehberli implant yerleştirilmesini takiben protezin sağ kalım oranını konvansiyonel implant yerleştirilmesi ile karşılaştırılmalıdır. Bununla birlikte flep kaldırmadan yapılan cerrahi işlemler gibi farklı klinik protokoller de rehberli cerrahinin etkinliğine katkıda bulunabilmektedir $^{51}$.

Geng ve $\operatorname{ark}^{48}$ yaptıkları çalışmada CAD/CAM tekniği ile gerçekleştirilen farklı tiplerde cerrahi rehberlerin kullanımı ile yerleştirilen implantların klinik sonuçlarını ve bu rehberlerin doğruluğunu değerlendirmişlerdir. CAD/CAM tekniği ile üretilen cerrahi rehberler kullanılarak 24 hastaya 111 implant yerleştirilmiştir. İmplant yerleştirildikten sonra yerleştirilen implantlar ile planlanmış olan implantların pozisyonları ve angulasyonları (açılanma) pre ve post-operatif BT görüntülerinin eşleştirildiği özel yazılım programı kulanılarak belirlenmiştir. Sapmalar hesaplanılmış ve farklı rehberler arasında karşılaştırılmalar yapılmıştır. Diş destekli cerrahi rehberlerin mukoza destekli olanlardan daha doğru sonuçlar verdiği ve hem kısmi hem de total olarak hazırlanmış rehberli şablonların cerrahi işlemi basitleştirdiği ve optimal implant yerleşimine yardımcı olabileceği sonucuna ulaşmışlardır.

Bilgisayar destekli cerrahi rehber üretimi tekniğinin tüm sistemle ilgili olarak özel eğitim ve özel ekipman gerektirmesi gibi olumsuz özellikleri bulunmaktadır. Bununla birlikte önemli teknik komplikasyonlar da gözlenmiştir ${ }^{15}$. Komplikasyonların; hatalı planlama, hatalı radyografik stent, tarama esnasında oluşan hatalar, yazılım planlaması, cerrahi stentin hızlı prototipleme ile üretimi, protez için bilginin transfer edilmesi ile ilgili olduğu kaydedilmiştir. Klinisyen bu hataların kaynağını fark ederse hataları en aza indirmek ve hasta tedavisini optimize etmek için çaba gösterecektir $^{15,52}$.

Block ve $a^{52}$ BT rehberli cerrahi komplikasyonları ve çözümlerini Tablo 6'daki gibi sıralamıştır.

Tablo 6. BT rehberli cerrahi komplikasyonları ve çözümleri

\begin{tabular}{|c|c|}
\hline Komplikasyon & Çözümler \\
\hline $\begin{array}{l}\text { BT taraması esnasında ideal } \\
\text { kurulumun kullanılmaması }\end{array}$ & $\begin{array}{l}\text { Kurulum, planlanmış insizal kenar } \\
\text { ve gingival marjini içeren var olan } \\
\text { protez ya da diagnostik wax-up } \\
\text { çalışmasının bir kopyası olmalıdır. }\end{array}$ \\
\hline $\begin{array}{l}\text { Duplike edilmiş olan protezin } \\
\text { dokuya tam olmayan uyumu } \\
\text { sonucu radyografik protezin } \\
\text { malpozisyonu ya da protezin iç } \\
\text { yüzeyi ile mukoza arasındaki hava } \\
\text { boşluğu sonucu hatalı rehber } \\
\text { stentin üretimi }\end{array}$ & $\begin{array}{l}\text { Duplike edilen protez akrilik ile } \\
\text { astarlanabilir (yumuşak astar ile } \\
\text { değil). Tarama ve stent } \\
\text { yerleştirilmesi esnasında ısırma } \\
\text { kaydı kullanılabilir. }\end{array}$ \\
\hline $\begin{array}{l}\text { Okluzal desteğin olmaması } \\
\text { nedeniyle ağıza yerleştirildiğinde } \\
\text { stent oriyantasyonunun yetersiz } \\
\text { olması }\end{array}$ & $\begin{array}{l}\text { Cerrahi rehber stentte okluzal } \\
\text { durudurucular olmayabilir veya } \\
\text { kaybolmuş olabilir. Bu durumda } \\
\text { posterior dişleri kapsayan ısırma } \\
\text { kaydı kullanılmalıdır. }\end{array}$ \\
\hline $\begin{array}{l}\text { Hastanın tarama sırasında uygun } \\
\text { doğrultuda olmaması }\end{array}$ & $\begin{array}{l}\text { Hastane veya görüntüleme } \\
\text { merkezi kullanıldığında klinisyenin } \\
\text { iletişim hatalarını önlemek için } \\
\text { tarama seansında bulunması } \\
\text { gerekebilir. Dişlerin üst üste } \\
\text { gelmesini önlemek için okluzal } \\
\text { yüzeyleri ayırmak ve okluzal } \\
\text { düzleme paralel tarama yapııması } \\
\text { konusunda teknisyeni } \\
\text { yönlendirmede yazılı talimatlar } \\
\text { kullanılmalı. }\end{array}$ \\
\hline $\begin{array}{l}\text { Tarama esnasında hastanın } \\
\text { hareket etmesi }\end{array}$ & $\begin{array}{l}\text { Konik ışınlı tarayıcılarda bulunan } \\
\text { çene tutucuları ve alın bantları } \\
\text { hastanın sabit kalmasına yardımcı } \\
\text { olur. Tarama sırasında hastanın } \\
\text { hareketsiz olması ile taramanın } \\
\text { hastaya ulaştırıması gerekir. }\end{array}$ \\
\hline $\begin{array}{l}\text { Geniş dental restorasyon } \\
\text { artifaktının aksiyel görüntüyü } \\
\text { gizlemesi }\end{array}$ & $\begin{array}{l}\text { Yazılım uygulamaları ile bazı } \\
\text { saçılmalar elimine edilebilir. } \\
\text { Bununla birlikte çift tarama } \\
\text { tekniğinde saçılma artifaktını } \\
\text { engellemek için okluzal düzleme } \\
\text { radyoopak işaretleyiciler } \\
\text { koymaktan kaçınılmalıdır. }\end{array}$ \\
\hline $\begin{array}{l}\text { Maksiller ve mandibular dişlerin } \\
\text { üst üste gelmesinin dişlerin } \\
\text { pozisyonunu gizlemesi }\end{array}$ & $\begin{array}{l}\text { Dişleri birbirinden ayıran okluzal } \\
\text { ısırma kaydı kullanılmalı. }\end{array}$ \\
\hline $\begin{array}{l}\text { Radyografik tarama protezindeki } \\
\text { radyoopak malzemenin yetersiz } \\
\text { karıştırılması }\end{array}$ & $\begin{array}{l}\text { Baryum sülfat, polimer ile } \\
\text { karıştırılmadan önce monomer ile } \\
\text { karıştırılmalı. Karıştırılmadan önce } \\
\text { baryum sülfat tozu ince partiküller } \\
\text { haline getirilmeli. \%15'den daha } \\
\text { fazla kullanılmamalı. }\end{array}$ \\
\hline $\begin{array}{l}\text { Stent içerisine ana silindirin hatalı } \\
\text { yerleştirilmesi }\end{array}$ & $\begin{array}{l}\text { Rehber stent, implant sistemi ile } \\
\text { eşleştirilmeli. Klinisyen ameliyat } \\
\text { gününden önce rehber stenti } \\
\text { kontrol etmeli. }\end{array}$ \\
\hline $\begin{array}{l}\text { Rehber stentin içine yerleştirilen } \\
\text { sabitleme vidası tüplerinin sipariş } \\
\text { edilenden daha küçük olması }\end{array}$ & $\begin{array}{l}\text { Ameliyat gününden önce cerrahi } \\
\text { stent kontrol edilmeli. }\end{array}$ \\
\hline
\end{tabular}

(BT: Bilgisayarl 1 


\section{SONUÇ}

Günümüzde implant planlaması ve tedavisinde yararlanılacak çok sayıda görüntüleme yöntemi mevcut olup, hızla gelişmeye devam etmektedir. CAD/CAM ile inter aktif implant tedavi planlaması da yapılmaktadır. Diş hekimliğinde implant planlamasında panoromik görüntüleme yöntemi standart olarak kabul edilmektedir. KIBT görüntüleme spesifik vakalarda implant bölgesinin cerrahi öncesi değerlendirilmesinde, implant yerleşimi ve takibinin radyografik değerlendirilmesinde önemli bir role sahiptir. KIBT tekniğinden elde edilen görüntüler ve yazılım programlarının yardımı ile klinisyenler vital yapılardan kaçınarak estetik, fonksiyonel ve biyolojik talepleri karşılayabilen ideal pozisyonda implantlar yerleştirebilirler. Vital yapıların lokalizasyonunu tam olarak belirleyebilmek için MRG kullanılabilir. Tüm bu görüntüleme tekniklerinin her biri implant tedavisinin başarısını artırmada ve önemli komplikasyonların önlenmesinde rol oynamaktadır. Ancak hiçbir görüntüleme yöntemi mükemmel olmamakla beraber, her birinin avantaj ve dezavantajları vardır. Bu yüzden görüntüleme yöntemi seçimine, operasyon bölgesinin özellikleri, konulacak implant sayısı ve implant vakasının kompleksliği, cihaz maliyeti, hastanın özellikleri ve maruz kalacağı doz gibi pek çok değişken göz önünde bulundurularak; dikkatli ve detaylı bir inceleme sonucunda karar verilmelidir.

Gülfem Ergün: ORCID ID: 0000-0001-9981-5522 Zeynep Şahin: ORCID ID: 0000-0003-2459-2912

\section{'KAYNAKLAR}

1. Kayabasoglu G, Nacar A, Altundag A, Cayonu M, Muhtarogullari $M$, Cingi $C$. A retrospective analysis of the relationship between rhinosinusitis and sinus lift dental implantation. Head Face Med 2014;15:53-8.

2. Çakur B, Sümbüllü MA, Harorlı A. Operasyon öncesi implant yerlerinin belirlenmesinde radyolojik kriterler ve radyolojik teknik seçimi. Atatürk Üniv Diş Hek Fak Derg 2007;17:23-30.

3. Cochran DL, Nummikoski PV, Schoolfield JD, Jones AA, Oates TW. A prospective multicenter 5-year radiographic evaluation of crestal bone levelsover time in 596 dental implants placed in 192 patients. J Periodontol 2009;80:725-33.

4. Merheb J, Van Assche N, Coucke W, Jacobs R, Naert I, Quirynen M. Relationship between cortical bone thickness or computerized tomographyderivedbone density values and implant stability. Clin Oral Implants Res 2010;21:612-7.

5. Thakkar M, Mehta R, Joshi S, Sharma S. Implant Complications and Failures-A Review. Adv Hum Biol 2013;3:20-7.

6. Chan HL, Misch K, Wang HL. Dental imaging in implant treatment planning. Implant Dent 2010;19:288-98.

7. Harris $D$, Horner K, Gröndahl K, Jacobs R, Helmrot E, Benic GI, Bornstein MM, Dawood A, Quirynen M.E.A.O. guidelines for the use of diagnostic imaging in implant dentistry 2011. A consensus workshop organized by the European Association for Osseointegration at the Medical University of Warsaw. Clin Oral Implants Res 2012;23:1243-53.

8. Gupta S, Patil N, Solanki J, Singh R, Laller S. Oral Implant Imaging: A Review. Malays J Med Sci 2015; 22: 7-17.

9. Nagarajan A, Perumalsamy R, Thyagarajan R, Namasivayam A. Diagnostic imaging for dental implant therapy. J Clin Imaging Sci 2014;4:4-14.

10. Shruthi M, Sangeetha R, Singh AK, Kini R, Naik V. To Implant or not to Implant? The Role of Imaging. J Orofac Res 2013;3:210-7.

11. Bhoosreddy AR, Bhoosreddy S, Shirsekar VU. Implant Imaging. J Contemp Dent 2013;3:127-32.

12. Dagassan-Berndt DC, Zitzmann NU, Walter C, Schulze RK. Implant treatment planning regarding augmentation procedures: panoramic radiographs vs. cone beam computed tomography images. Clin Oral Implants Res 2015;30:1-7.

13. Du Toit J, Gluckman H, Gamil R, Renton T. Implant Injury Case Series and Review of the Literature Part 1: Inferior Alveolar Nerve Injury. J Oral Implantol 2015;41:144-51.

14. Sanchez Garces MA, Escoda-Francoli J, Gay-Escoda C. Implant Complications, Implant Dentistry-The Most Promising Discipline of Dentistry, Ilser Turkyilmaz (Ed.). 1 ed. Rijeka; Croatia: 2011. p.369-81.

15. D'Souza KM, Aras MA. Types of implant surgical guides in dentistry: a review. J Oral Implantol 2012;38:643-52.

16. De Kok IJ, Thalji G, Bryington M, Cooper LF. Radiographic stents: integrating treatment planning and implant placement. Dent Clin North Am 2014;58:181-92. 
17. Van Assche $N$, van Steenberghe $D$, Guerrero $M E$, Hirsch E, Schutyser F, Quirynen M, Jacobs R. Accuracy of implant placement based on presurgical planning of three-dimensional cone-beam images: a pilot study. J Clin Periodontol 2007;34:816-21.

18. Nickenig HJ, Wichmann M, Hamel J, Schlegel KA, Eitner $S$. Evaluation of the difference in accuracy between implant placement by virtual planning data and surgical guide templates versus the conventional free-hand method - a combined in vivo - in vitro technique using cone-beam CT (Part II). J Craniomaxillofac Surg 2010;38:488-93.

19. Nickenig $\mathrm{HJ}$, Eitner S. Reliability of implant placement after virtual planning of implant positions using cone beam CT data and surgical (guide) templates. J Craniomaxillofac Surg 2007;35:207-11.

20. Liang X, Jacobs R, Martens W, Hu Y, Adriaensens P, Quirynen M, Lambrichts I. Macro- and microanatomical, histological and computed tomography scan characterization of the nasopalatine canal. J Clin Periodontol. 2009;36:598-603.

21. Neves FS, Crusoé-Souza M, Franco LC, Caria PH, Bonfim-Almeida P, Crusoé-Rebello I. Canalis sinuosus: a rare anatomical variation. Surg Radiol Anat 2012;34:563-6.

22. Mardinger O, Namani-Sadan N, Chaushu G, Schwartz-Arad D. Morphologic changes of the nasopalatine canal related to dental implantation: a radiologic study in different degrees of absorbed maxillae. J Periodontol 2008;79:1659-62.

23. Jacobs $R$, Lambrichts I, Liang $X$, Martens W, Mraiwa $N$, Adriaensens $P, \quad$ Gelan J.Neurovascularization of the anterior jaw bones revisited using high-resolutionmagnetic resonance imaging. Oral Surg Oral Med Oral Pathol Oral Radiol Endod 2007;103:683-93.

24. Kusum CK, Mody PV, Indrajeet, Nooji D, Rao SK, Wankhade BG. Interforaminal hemorrhage during anterior mandibular implant placement: An overview. Dent Res J (Isfahan) 2015;12:291-300.

25. Tagaya A, Matsuda Y, Nakajima K, Seki K, Okano $T$. Assessment of the blood supply to the lingual surface of the mandible for reduction of bleeding during implant surgery. Clin Oral Implants Res 2009;20:351-5.
26. Gültekin S, Araç M, Celik H, Karaosmaoğlu AD, Işık S. Mandibulanın lingual vasküler kanallarının dental BT ile değerlendirilmesi. Tanı Girisim Radyol 2003;9:188-91.

27. Vazquez L, Saulacic N, Belser U, Bernard JP. Efficacy of panoramic radiographs in the preoperative planning of posterior mandibular implants: a prospective clinical study of 1527 consecutively treated patients. Clin Oral Implants Res 2008;19:81-5.

28. Kütük N, Gönen ZB, Yaşar MT, Demirbaş $A E$, Alkan A. Reliability of panoramic radiography in determination of neurosensory disturbances related to dental implant placement in posterior mandible. Implant Dent 2014;23:648-52.

29. Alhassani AA, AlGhamdi AS. Inferior alveolar nerve injury in implant dentistry: diagnosis, causes, prevention, and management. J Oral Implantol 2010;36:401-7.

30. Gómez-Román G, Lautner NV, Goldammer C, McCoy M. Anterior Loop of the Mandibular Canal-A Source of Possible Complications. Implant Dent 2015;24:578-85.

31. Momota Y, Kani K, Takano H, Azuma M. Cerebellopontine angle mass mimicking lingual nerve injury after dental implantplacement: a case report. Aust Dent J 2015;60:412-5.

32. Torres MG, de Faro Valverde L, Vidal MT, CrusoéRebello IM. Branch of the canalis sinuosus: a rare anatomical variation--a case report. Surg Radiol Anat 2015;37:879-81.

33. Leckel M, Kress B, Schmitter M. Neuropathic pain resulting from implant placement: case report and diagnostic conclusions. J Oral Rehabil 2009;36:543-6.

34. Tadinada A, Fung K, Thacker S, Mahdian M, Jadhav A, Schincaglia GP. Radiographic evaluation of the maxillary sinus prior to dental implant therapy: A comparison between two-dimensional and three-dimensional radiographic imaging. Imaging Sci Dent $2015 ; 45: 169-74$.

35. Guerrero ME, Noriega J, Jacobs R. Preoperative implant planning considering alveolar bone grafting needs and complication prediction using panoramic versus $\mathrm{CBCT}$ images. Imaging Sci Dent 2014;44:213-20.

36. Galindo-Moreno P, Padial-Molina M, Avila G, Rios $H F$, Hernández-Cortés $P$, Wang HL. Complications

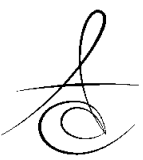


associated with implant migration into the maxillary sinus cavity. Clin Oral Implants Res 2012;23:1152-60.

37. Shahbazian M, Vandewoude C, Wyatt J, Jacobs R. Comparative assessment of panoramic radiography and $\mathrm{CBCT}$ imaging for radiodiagnostics in the posterior maxilla. Clin Oral Investig 2014;18:293300.

38. Rege IC, Sousa TO, Leles CR, Mendonça EF. Occurrence of maxillary sinus abnormalities detected by cone beam CT in asymptomatic patients. BMC Oral Health 2012;30:1-7.

39. Fortin T, Camby E, Alik M, Isidori M, Bouchet $H$. Panoramic images versus three-dimensional planning software for oral implant planning in atrophied posterior maxillary: a clinical radiological study. Clin Implant Dent Relat Res 2013;15:198204.

40. de Rezende Barbosa GL, Ramírez-Sotelo LR, Távora Dde $M$, de Almeida SM. Vertical measurements for planning palatal mini-implants in lateral radiography and cone beam computed tomography. Implant Dent 2014;23:588-92.

41. Jung BA, Wehrbein $H$, Heuser $L$, Kunkel M. Vertical palatal bone dimensions on lateral cephalometry and cone-beam computed tomography: implications for palatal implant placement. Clin Oral Implants Res 2011;22:664-8.

42. Chan HL, Benavides $\mathrm{E}$, Yeh CY, Fu JH, Rudek IE, Wang HL. Risk assessment of lingual plate perforation in posterior mandibular region: a virtual implant placement study using cone-beam computed tomography. J Periodontol 2011;82:12935.

43. Peker I, Alkurt MT, Michcioglu T. The use of 3 different imaging methods for the localization of the mandibular canal in dental implant planning. Int J Oral Maxillofac Implants 2008;23:463-70.

44. Hämmerle $\mathrm{CH}$, Cordaro $\mathrm{L}$, van Assche N, Benic GI, Bornstein M,Gamper F, Gotfredsen K, Harris D, Hürzeler M, Jacobs R, Kapos T, Kohal RJ, Patzelt SB, Sailer I, Tahmaseb A, Vercruyssen $M$, Wismeijer D.Digital technologies to support planning, treatment, and fabrication processesand outcome assessments in implant dentistry. Summary and consensus statements. The 4th EAO consensus conference 2015. Clin Oral Implants Res 2015;26:97-101.
45. Vercruyssen M, Laleman I, Jacobs R, Quirynen M.Computer-supported implant planning and guided surgery: a narrative review. Clin Oral Implants Res 2015;26:69-76.

46. Jung RE, Schneider D, Ganeles J, Wismeijer D, Zwahlen M, Hämmerle $\mathrm{CH}$, TahmasebA. Computer technology applications in surgical implant dentistry: a systematic review. Int J Oral Maxillofac Implants 2009;24:92-109.

47. Stapleton BM, Lin WS, Ntounis A, Harris BT, Morton D. Application of digital diagnostic impression, virtual planning, and computer-guided implant surgery for a CAD/CAM-fabricated, implant-supported fixed dental prosthesis: a clinical report. J Prosthet Dent 2014;112:402-8.

48. Geng W, Liu C, Su Y, Li J, Zhou Y. Accuracy of different types of computer-aided design/computer-aided manufacturing surgical guides for dental implant placement. Int J Clin Exp Med 2015;8:8442-9.

49. Tahmaseb A, Wismeijer D, Coucke W, Derksen W. Computer technology applications in surgical implant dentistry: a systematic review. Int J Oral Maxillofac Implants 2014;29: 25-42.

50. Ersoy AE, Turkyilmaz I, Ozan O, McGlumphy EA. Reliability of implant placement with stereolithographic surgical guides generated from computed tomography: clinical data from 94 implants. J Periodontol 2008;79:1339-45.

51. Vercruyssen M, Hultin M, Van Assche N, Svensson K, Naert I, Quirynen M. Guided surgery: accuracy and efficacy. Periodontol 2000 2014;66:228-46.

52. Block MS, Chandler C. Computed tomographyguided surgery: complications associated with scanning, processing, surgery, and prosthetics. ] Oral Maxillofac Surg 2009;67:13-22.

\author{
Yazışma Adresi \\ Dr. Öğr. Üyesi: Zeynep ŞAHİN \\ Mersin Üniversitesi Diş Hekimliği Fakültesi \\ Protetik Diş Tedavisi \\ Çiftlikköy Kampüsü, Yenişehir / MERSİN \\ TIf: 0 (324) 3610037 \\ e-mail: dtsahinzeynep81@gmail.com
}

